\title{
Trends of multiple sclerosis in Nineveh province
}

\author{
Abbas Ahmed Younis*, Ammar H. Yahia** \\ * Al-Arabi Family Center, Nineveh Directory of Health; ${ }^{\star \star}$ Al-Quds Family Center, Nineveh Directory of Health; \\ Mosul, Iraq. \\ Correspondence: Ammar H. Yahia. dr.ammarhazem65@yahoo.com.
}

(Ann Coll Med Mosul 2018; 40 (2): 63-68).

Received: $8^{\text {th }}$ Apr. 2018; Accepted: $9^{\text {th }}$ Sep. 2018.

\begin{abstract}
Background: Multiple sclerosis is the major cause of non-traumatic disability in young adults worldwide with considerable social impact and economic consequences. It is a multifactorial disease with different epidemiological patterns and clinical presentations in various populations.

Aim: This study was conducted to calculate the disease prevalence in Nineveh Governorate, explaining the demographic features, characterizing the clinical and epidemiological features of multiple sclerosis, and finding possible variations in some features of the disease compared to other regions.

Materials and methods: A total of 136 patients from both sexes with confirmed MS who are living in Nineveh Governorate and attending MS Clinic at Ibn-Sina Teaching Hospital, were enrolled in this study during a period of 7 months from October 2011 to April 2012. Data were collected from filing system of MS Clinic and from direct interview with the patients (78 patients).

Results: The prevalence of MS calculated to be $4.72 / 100,000$. MS affects females more than males in Nineveh (88 females- $64.7 \%$; 48 males- $35.3 \%$ ) with a female to male ratio (1.83:1), and a mean age of onset (30.9) years and mean age of presentation (39.5) years with an average delay of (8.5) years in diagnosis of the disease. The disease mostly affects the age range (20-50) years age. Family history was found in $(8.8 \%)$ of patients. Most of MS patients in Nineveh were well educated and some of them with higher educational degrees, and majority of patients (68\%) were living in Mosul city. The most frequent initial symptom of disease was weakness in one or more limbs $(36.8 \%)$, followed by ataxia (14\%), and visual disturbance (13.2\%). A relapsing remitting pattern was the most frequent category of the disease $(78.7 \%)$.

Conclusions: The study showed that MS is rare in Nineveh Governorate which is considered to be a low risk area for MS, and the characteristics of the disease are nearly comparable to findings of other studies in Iraq and Middle eastern region.
\end{abstract}

Keywords: Multiple sclerosis, trends, Nineveh.

$$
\begin{aligned}
& \text { أنماط مرض التصلب اللويحي المتعدد في محافظة نينوى }
\end{aligned}
$$

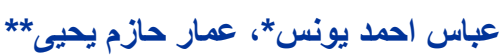

$$
\begin{aligned}
& \text { *مركز صحي العربي لطب الأسرة ، دائرة صحة نينوى، ** مركز صحي القدس لطب الأسرة ، دائرة صحة نينوى ، الموصل ، العراق } \\
& \text { مقدمة: يعد مرضلاصة التصلب اللويحي التتعدد السبب الرئيسي بعد إصابات الحوادث لحالات العجز و الإعاقة عند البالغين الثباب. }
\end{aligned}
$$

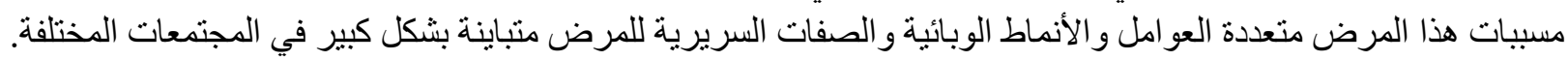

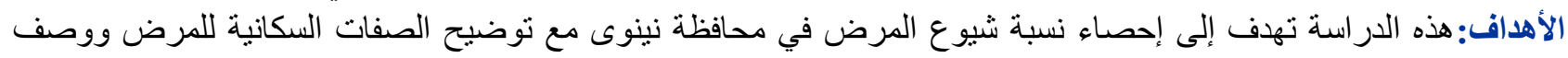

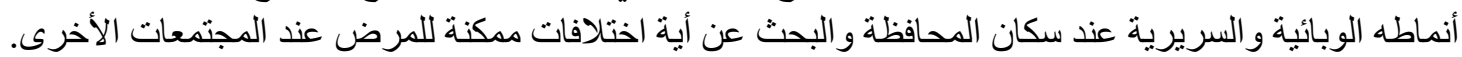

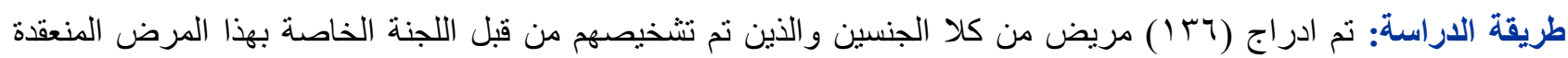

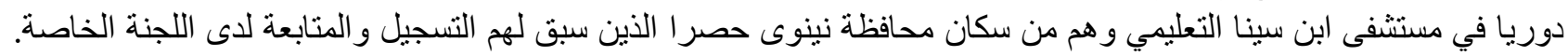

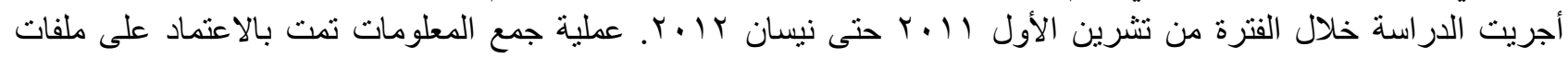

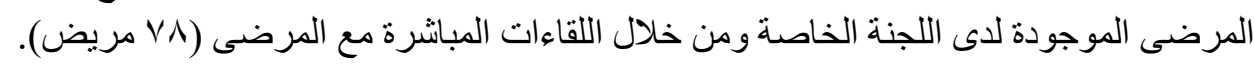




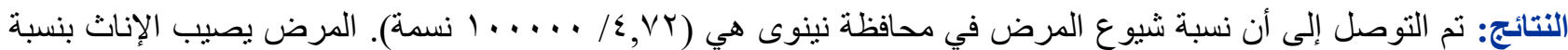

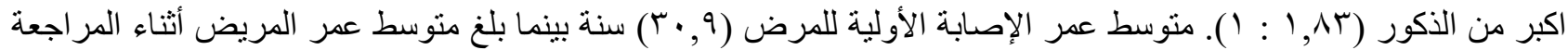

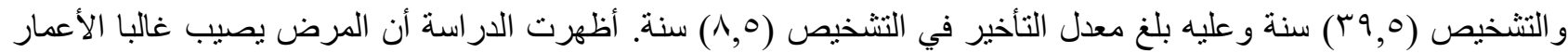

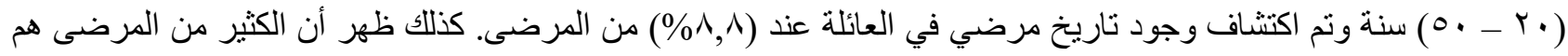

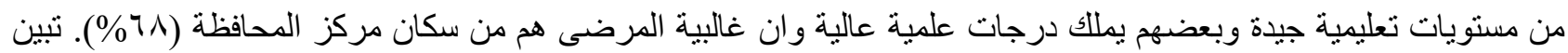

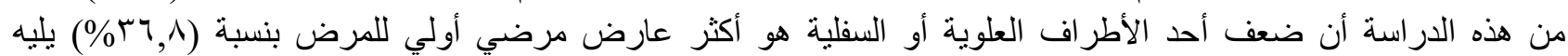

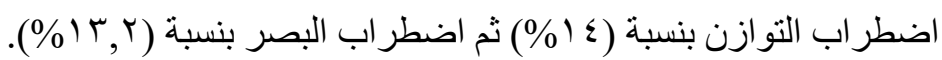

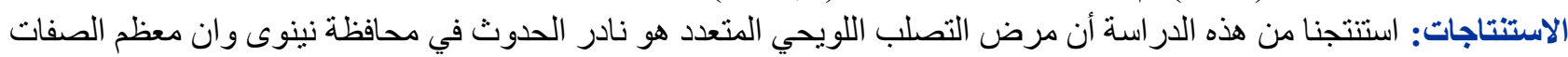
السكانية و السريرية للمرض مشابهة لنتائج دراسات أخرى عن المرض في العر اق وفي الشرق الأوسط. الكلمات المفتاحية: مرض وضرية التصلب اللويحي المتعدد، نمط، نينوى.

\section{INTRODUCTION}

$\mathrm{D}$ emyelinating disorders are immunemediated conditions characterized by preferential destruction of central nervous system (CNS) myelin. ${ }^{1}$ The peripheral nervous system (PNS) is spared, and most patients have no evidence of an associated systemic illness. ${ }^{1}$ Multiple sclerosis (MS), the most common disease in this category, is second only to trauma as a cause of neurologic disability beginning in early to middle adulthood. ${ }^{1}$ Multiple sclerosis is the major cause of non-traumatic disability in young adults with considerable social impact and economic consequences. It is a multifactorial disease with different epidemiological patterns and clinical presentations in various populations ${ }^{1}$.

Multiple sclerosis (MS) is a chronic disease characterized by inflammation, demyelination, gliosis (scarring), and neuronal loss; the course can be relapsing-remitting or progressive. ${ }^{1}$ Lesions of MS typically occur at different times and in different CNS locations (i.e., disseminated in time and space). MS affects 350,000 individuals in the United States and 2.5 million individuals worldwide. ${ }^{1}$ Manifestations of MS vary from a benign illness to a rapidly evolving and incapacitating disease requiring profound lifestyle adjustments. ${ }^{1}$

The cause of MS is unknown, but it is likely that multiple factors (not a single identifiable agent or event) act in concert to trigger or perpetuate the disease. These factors are in part environmental and in part hereditary. ${ }^{2}$

Incidence is low in childhood, increases rapidly after age 18, reaches a peak between 25 and 35 years (about 2 years earlier in women than men), and then slowly declines, becoming rare at age 50 and older. ${ }^{3}$ Risk is greater in women than in men; the female-to-male ratios are $1.5-2.5: 1$ in most populations. ${ }^{4}$

MS is rare in Asia, and in all continents, it is rare in the tropics and subtropics. Within regions of temperate climate, MS incidence and prevalence increase with latitude, both north and south of the equator. ${ }^{5}$

The onset of MS may be abrupt or insidious. Symptoms may be severe or seem so trivial that a patient may not seek medical attention for months or years. ${ }^{1}$ Clinical presentation is a function of the site of the inflammatory process. Attacks are by definition those that produce symptoms that last more than 24 hours. $^{6}$

\section{Criteria for Categorizing $\mathbf{M S}^{7,8}$}

MS is divided into the following categories on the basis of clinical and radiologic criteria, including the frequency of clinical relapses, time to disease progression, and lesion development on Magnetic resonance image (MRI):

- Relapsing-remitting MS (RRMS).

- Secondary progressive MS (SPMS).

- Primary progressive MS (PPMS).

- Progressive-relapsing MS (PRMS).

Mosul city is the capital of Nineveh province, located north of Iraq (subtropical country), its latitude 36.34 and longitude 43.12. During the period of the study the population number of Nineveh was around (2881355) according to Nineveh registry center.

\section{Aim and objectives}

This study was conducted to describe the trend of Multiple Sclerosis in the population of Nineveh 
Governorate through conducting the following objectives:

1. Calculating the prevalence of MS in Nineveh Governorate.

2. Describing the socio-demographic characteristics of the study population.

3. Describing the main clinical presentation of multiple sclerosis.

4. Describing the common clinical and diagnostic categories of MS.

\section{PATIENTS AND METHODS}

This study was conducted in Multiple Sclerosis Clinic at Ibn-Sina Teaching Hospital in Mosul City over a period of seven months extending from the $1^{\text {st }}$ of October 2011 to the end of April 2012. A case series design was adopted in order to achieve the objectives of this study. The study population (136 patients) includedall confirmed cases of MS living in Nineveh Governorate who are registered and receiving treatment by this clinic. Every patient was diagnosed by neurologists according to McDonald's criteria and confirmed by the special committee held in the Multiple Sclerosis Clinic and registered in the file system organized in the clinic. A special questionnaire form were prepared for this study. This form included information regarding the patient's name, age, sex, ethnicity, educational level, residence, family history of MS, date of clinical onset, initial symptoms, and the diagnostic category of MS. The diagnostic categories of MS which include clinically definite (definitely have MS), clinically probable (probably have MS), and clinically indefinite (need more revision or waiting for another attack) were categorized according to McDonald's criteria. These data were filled for each patient through direct interview (78 patients) and from the filing system of MS clinic. Data had been collected on Excel program in the computer and statistical analysis had been done to them. Prevalence rate of MS had been estimated and categorized depending on Kurtzke's global scale (low $<5$, medium 5-25, high $>30$ per 100,000 population $)^{9}$. An official agreement was obtained from the directorate of health in Mosul before conducting this study.

\section{RESULTS}

During the study period, a total of 136 individuals living in Nineveh Governorate are reported to be affected by MS. The prevalence of MS in Nineveh Governorate was estimated to be $4.72 / 100,000$ (low prevalence according to Kurtzke's scale). Females were found to have a higher prevalence (3.05) than males (1.67) per 100,000 population. The female to male ratio calculated to be $(1.83: 1)$. The patients were among the age range (16-68) years. The mean age of initial visit to the Multiple Sclerosis Clinic was (39.50) years while the mean age of onset of disease was (30.95) years, so there is an average delay of (8.55) years in diagnosis of the disease. Table 1 shows that there was more than (3) years earlier onset of disease in females than males, and there was a longer delay time in diagnosis of male patients than female ones.

Table 2 demonstrates the distribution of cases for each decade at presentation\&onset for both sexes and it is clear that most cases were among $(20-50)$ years age rangeand it shows that most cases were in the $3^{\text {rd }}$ and $4^{\text {th }}$ decade of life at onset and in the $4^{\text {th }}$ and $5^{\text {th }}$ decade at presentation.

Family History: A family history of MS was identified in 12 patients out of total 136 (8.82\%).

Ethnicity: Table $\mathbf{3}$ shows that more than half of all cases were Arab females, and the females affected were more than males for all ethnicities except Turkmen males.

Educational Level and disease: Table 4 shows that 3 patients $(2.3 \%)$ had a Ph.D degree, 4 patients $(2.9 \%)$ had a master degree, only 2 patients were illiterates, and more than $(42 \%)$ of our patients have a high school graduation certificate.

Residence: Majority of our patients were living in Mosul city $(67.6 \%)$, while less than $1 / 3$ of patients $(32.4 \%)$ were living outside the city within the boundaries of Nineveh Governorate.

Clinical Manifestations: Weakness in one or more limbs was the most frequent initial symptom stated by more than $1 / 3$ of patients followed by sensory disturbance and ataxia, see Table 5.

Clinical Categories: A relapsing remitting pattern was identified in (78.7\%) of patients and so it is the most frequent pattern of MS in Nineveh Governorate, see Table 6. 
Diagnostic Categories: Majority of cases were reported as being "Clinically Definite", while less than $(3 \%)$ of cases were reported as "Clinically Indefinite" cases and the rest being reported as "Clinically Probable" according to McDonald's criteria. See Table 7.
Table 1. Mean age of presentation and onset, and the average delay in diagnosis.

\begin{tabular}{lccc}
\hline Gender & $\begin{array}{c}\text { Mean age of } \\
\text { onset } \\
\text { (years) }\end{array}$ & $\begin{array}{c}\text { Mean age of } \\
\text { presentation } \\
\text { (years) }\end{array}$ & $\begin{array}{c}\text { Average } \\
\text { delay in } \\
\text { diagnosis } \\
\text { (years) }\end{array}$ \\
\hline Female & 29.82 & 37.96 & 8.14 \\
Male & 33.00 & 42.21 & 9.21 \\
Both & 30.95 & 39.50 & 8.55 \\
\hline
\end{tabular}

Table 2. Distribution of cases for each decade at time of presentation and at onset.

\begin{tabular}{|c|c|c|c|c|c|c|c|c|c|c|c|c|}
\hline \multirow{3}{*}{ Gender } & \multicolumn{12}{|c|}{ Age (years) } \\
\hline & \multicolumn{2}{|c|}{$10-19$} & \multicolumn{2}{|c|}{$20-29$} & \multicolumn{2}{|c|}{$30-39$} & \multicolumn{2}{|c|}{$40-49$} & \multicolumn{2}{|c|}{$50-59$} & \multicolumn{2}{|c|}{$>60$} \\
\hline & No. & $\%$ & No. & $\%$ & No. & $\%$ & No. & $\%$ & No. & $\%$ & No. & $\%$ \\
\hline Male & 1 & 0.7 & 6 & 4.4 & 11 & 8.1 & 24 & 17.7 & 3 & 2.2 & 3 & 2.2 \\
\hline Female & 0 & 0 & 23 & 16.9 & 33 & 24.3 & 23 & 16.9 & 7 & 5.1 & 2 & 1.5 \\
\hline At onset (both sex) & 14 & 10.3 & 47 & 34.6 & 50 & 36.8 & 20 & 14.7 & 4 & 2.9 & 1 & 0.7 \\
\hline
\end{tabular}

Table 3. Distribution of cases according to ethnicity for each sex.

\begin{tabular}{lcccccc}
\hline \multirow{2}{*}{ Ethnicity } & \multicolumn{2}{c}{ Females } & \multicolumn{2}{c}{ Males } & \multicolumn{2}{c}{ Total } \\
\cline { 2 - 7 } Arabs & No. & $\%$ & No. & $\%$ & No. & $\%$ \\
Turkmens & 75 & 55.15 & 41 & 30.14 & 116 & 85.29 \\
Kurds & 4 & 2.94 & 6 & 4.41 & 10 & 7.35 \\
Assyrians & 8 & 5.88 & 1 & 0.74 & 9 & 6.62 \\
Total & 1 & 0.74 & 0 & 0 & 1 & 0.74 \\
\hline
\end{tabular}

Table 4. Educational level of patients with MS.

\begin{tabular}{|c|c|c|c|c|c|c|}
\hline \multirow{2}{*}{ Educational Level } & \multicolumn{2}{|c|}{ Females } & \multicolumn{2}{|c|}{ Males } & \multicolumn{2}{|c|}{ Total } \\
\hline & No. & $\%$ & No. & $\%$ & No. & $\%$ \\
\hline Ph.D degree & 3 & 2.3 & 0 & 0.0 & 3 & 2.3 \\
\hline Master degree & 2 & 1.47 & 2 & 1.47 & 4 & 2.9 \\
\hline High school & 26 & 19.1 & 25 & 18.4 & 51 & 37.5 \\
\hline Preparatory school & 14 & 10.3 & 7 & 5.1 & 21 & 15.4 \\
\hline Secondary school & 11 & 8.1 & 4 & 2.9 & 15 & 11.0 \\
\hline Elementary school & 30 & 22.0 & 10 & 7.4 & 40 & 29.4 \\
\hline Illiterate & 2 & 1.5 & 0 & 0 & 2 & 1.5 \\
\hline Total & 88 & 64.7 & 48 & 35.3 & 136 & 100 \\
\hline \multirow{2}{*}{ Initial Symptom } & \multicolumn{2}{|c|}{ Females } & \multicolumn{2}{|c|}{ Males } & \multicolumn{2}{|c|}{ Total } \\
\hline & No. & $\%$ & No. & $\%$ & No. & $\%$ \\
\hline Limb Weakness & 34 & 25 & 16 & 11.8 & 50 & 36.8 \\
\hline Sensory Disturbance & 21 & 15.4 & 5 & 3.6 & 26 & 19 \\
\hline Ataxia & 10 & 7.4 & 9 & 6.6 & 19 & 14 \\
\hline Visual Disturbance & 8 & 5.9 & 10 & 7.3 & 18 & 13.2 \\
\hline Vertigo & 6 & 4.4 & 5 & 3.7 & 11 & 8.1 \\
\hline Diplopia & 2 & 1.4 & 4 & 3.0 & 6 & 4.4 \\
\hline Complete visual loss & 2 & 1.5 & 2 & 1.5 & 4 & 3 \\
\hline Facial Palsy & 3 & 2.3 & 1 & 0.7 & 4 & 3 \\
\hline Trigeminal Neuralgia & 1 & 0.7 & 0 & 0 & 1 & 0.7 \\
\hline Bladder problems & 1 & 0.7 & 0 & 0 & 1 & 0.7 \\
\hline Lhermitte's phenomenon & 0 & 0 & 1 & 0.7 & 1 & 0.7 \\
\hline Slurred speech & 1 & 0.7 & 0 & 0 & 1 & 0.7 \\
\hline Dysphagia & 0 & 0 & 1 & 0.7 & 1 & 0.7 \\
\hline Loss of consciousness & 1 & 0.7 & 0 & 0 & 1 & 0.7 \\
\hline
\end{tabular}


Table 6. Clinical categories of MS in Nineveh Governorate.

\begin{tabular}{|c|c|c|c|c|c|c|}
\hline \multirow{2}{*}{ Category } & \multicolumn{2}{|c|}{ Females } & \multicolumn{2}{|c|}{ Males } & \multicolumn{2}{|c|}{ Total } \\
\hline & No. & $\%$ & No. & $\%$ & No. & $\%$ \\
\hline $\begin{array}{l}\text { Relapsing } \\
\text { Remitting }\end{array}$ & 66 & 48.5 & 41 & 30.2 & 107 & 78.7 \\
\hline $\begin{array}{l}\text { Secondary } \\
\text { Progressive }\end{array}$ & 10 & 7.4 & 7 & 5.1 & 17 & 12.5 \\
\hline $\begin{array}{l}\text { Progressive } \\
\text { Relapsing }\end{array}$ & 5 & 3.7 & 0 & 0.0 & 5 & 3.7 \\
\hline $\begin{array}{l}\text { Primary } \\
\text { Progressive }\end{array}$ & 2 & 1.4 & 0 & 0.0 & 2 & 1.4 \\
\hline $\begin{array}{l}\text { Clinically } \\
\text { Isolated } \\
\text { Syndrome }\end{array}$ & 5 & 3.7 & 0 & 0.0 & 5 & 3.7 \\
\hline
\end{tabular}

Table 7. Diagnostic categories of MS cases.

\begin{tabular}{lcccccc}
\hline Diagnostic & \multicolumn{2}{c}{ Females } & \multicolumn{2}{c}{ Males } & \multicolumn{2}{c}{ Total } \\
\cline { 2 - 7 } Category & No. & $\%$ & No. & $\%$ & No. & $\%$ \\
Clinically & 77 & 56.6 & 35 & 25.8 & 112 & 82.4 \\
Definite & & & & & & \\
Clinically & 8 & 5.9 & 12 & 8.8 & 20 & 14.7 \\
Probable & 3 & 2.2 & 1 & 0.7 & 4 & 2.9 \\
Indefinite & 88 & 64.7 & 48 & 35.3 & 136 & 100 \\
\hline Total & & & & & & \\
\hline
\end{tabular}

\section{DISCUSSION}

In this study the prevalence of multiple sclerosis in Nineveh was recorded to be $(4.72 / 100,000)$ and this is nearly similar to the figure provided by Atlas of Multiple Sclerosis Resources in the World 2008 by WHO which estimates the prevalence of MS in Iraq to be in the range of $(5.01-20)^{10}$. On the other hand, this result is significantly lower than what was reported in a study conducted in Istanbul in Turkey by Ülkü Türk Börü, et $\mathrm{al}^{11}$ which was $(101.4 / 100,000)$ and this might be due to different geographical location and different ethnicity between Istanbul and Mosul. Two other studies done by Saadatnia $\mathrm{M}$, et $\mathrm{al}^{12}$ in Isfahan, Iran, and by Jasem Al-Hashel, et al $^{13}$ in Jordan reported a high prevalence of MS $(43.8 / 100,000,39 / 100,000$ respectively).

The female to male ratio in this study estimated to be $1.83: 1$ and this figure is nearly comparable to the figure of WHO Atlas of $\mathrm{MS}^{10}$ which was (2:1), and to the figure of a study conducted in Kuwait at 2012 by R. Alroughani ${ }^{14}$ which was 1.95:1.

In this study, it was found that the mean age of onset of disease in Nineveh Governorate was (30.95) years and this figure is comparable to the figure of Iraqi study by Al-Araji A, et al ${ }^{15}$ (29.2) years.
The mean age of presentation in our study is (39.5) years with an average delay (8.5) years in diagnosis of the disease, this figure is slightly higher than the figure of Al-Araji $\mathrm{A}$, et $\mathrm{al}^{15}$ which was (37.6) years.

During the study period, a positive family history was identified in $1^{\text {st }}$ and $2^{\text {nd }}$ degree relatives in $(8.82 \%)$ of the patients and this figure is nearly comparable to a study on mixed Iraqi and Jordanian patients by Al-Shimmery and Bzaini ${ }^{16}$ which identified a positive family history in $(9.6 \%)$ of their patients.

The results of this study revealed that most of the patients were well educated, being either college graduates $(42.7 \%)$ with some of them had post-graduate degrees in different sciences $(5.2 \%)$, or having at least secondary school degree (26.4\%). The Iraqi-Jordanian study by AlShimmery and Bzaini ${ }^{16}$ also stated higher figures concerning college graduates and secondary school graduates $(50 \%, 40.4 \%$ respectively).

The most frequent initial symptom in this study was weakness in one or more limbs stated by $(36.8 \%)$ of the patients. Two other studies done by Al-Araji A, et $\mathrm{al}^{15}$ in Iraq and by Daif AK, et al ${ }^{17}$ in Saudi Arabia also mentioned high frequency rate of limb weakness, being the main presenting symptom (31.7\%, 56.9\% respectively). The difference in figures of the patients in these three studies despite being mostly of Arab ethnicity may be attributed to variation in data collection, environment, and possibly other unknown factors. Several studies reported motor weakness being more prevalent symptom among Arabs even in Iran.

The dominant pattern of clinical course of disease in this study was relapsing remitting in $(78.7 \%)$. The studies done by Al-Shimmery and Bzaini $^{16}$ in 2008 and by Al-Araji A, et al ${ }^{15}$ in 2005 also reported high frequency rate of relapseremission course $(84.6 \%, 66.3 \%$ respectively).

\section{CONCLUSIONS}

This study showed that the prevalence rate of MS in Nineveh province is low. It predominantly affects females, young ages (20 - 40 yeas), and all ethnic groups. Most patients are of high educational level and live in Mosul city. Motor weakness is the main presenting symptom. The dominant clinical pattern of MS in Nineveh is relapsing - remitting type. 


\section{REFERENCES}

1.Stephen L. Hauser. Multiple Sclerosis and Other Demyelinating Diseases, in: Dan L. Longo, Dennis L. Kasper, J. Larry Jameson, Anthony S. Fauci, Stephen L. Hauser, Joseph Loscalzo, Editors. Harrison's Principles of Internal Medicine. $18^{\text {th }}$ ed. New York, NY: McGraw Hill Medical; 2012: Ch.380.

2.Sharon W, Kenneth GW. Multiple sclerosis. World Health Organization. Geneva. 2001.

3.Koch-Henriksen N, Hyllested K. Epidemiology of multiple sclerosis: incidence and prevalence rates in Denmark 1948-64 based on the Danish Multiple Sclerosis Registry. Acta Neurol Scand 1988; 78: 369380.

4.Orton SM, Herrera BM, Yee IM, et al. Sex ratio of multiple sclerosis in Canada: a longitudinal study. Lancet Neurol 2006; 5: 932-936.

5.Kurtzke JF. MS epidemiology worldwide. One view of current status. Acta Neurol Scand 1995; 161(suppl): 2333.

6.Beatty WW. Cognitive and emotional disturbances in multiple sclerosis. Neurol Clin North Am 1993;11:189.

7.Polman $\mathrm{CH}$, Reingold SC, Edan G, Filippi M, Hartung HP, Kappos L, et al. Diagnostic criteria for multiple sclerosis: revisions to the "McDonald Criteria". Ann Neurol. Dec 2005;58(6):840-6.

8.McDonald WI, Compston A, Edan G, Goodkin D, Hartung HP, Lublin FD, et al. Recommended diagnostic criteria for multiple sclerosis: guidelines from the International Panel on the diagnosis of multiple sclerosis. Ann Neurol. Jul 2001;50(1):121-7.
9.J.F.Kurtzke,"A reassessment of the distribution of multiple sclerosis - part1", Acta Neurologica Scandinavica $1975 ; 51(2): 110$ - 136,

10.World Health Organization. Atlas of Multiple Sclerosis Resources in the World 2008. Available at:http:// www.who.int/mental_health/neurology/Atlas_MS_WEB. 11.Ülkü Türk Börü, Recep Alp, Haydar Sur, Levent Gül. Prevalence of Multiple Sclerosis Door-to-Door Survey in Maltepe, Istanbul, Turkey. Neuroepidemiology.2006;27:17-21.

12.Saadatnia $M$, Etemadifar $M$, Maghzi $A H$. Multiple sclerosis in Isfahan, Iran. Int Rev Neurobiol. 2007; 79:357.

13.Jasem Al-Hashel, Aaron D. Besterman, Christina Wolfson. The Prevalence of Multiple Sclerosis in the Middle East, Neuroepidemiology. 2008;31:129-137.

14.R.Alroughani, A.Ashkanani, S. Lamdhade. Clinical Characteristics of Multiple Sclerosis in Kuwait: Data From the New MS Registry of Amiri Hospital. February 2012;122( 2):82-87.

15.Al-Araji A, Mohammed Al. Multiple sclerosis in Iraq: does it have the same features encountered in Western countries? J Neurol Sci.2005 Jul 15;234(1-2):67-71.

16.Ehsan k. Al-Shimmery, Aso S.Bzaini. Multiple Sclerosis in Jordan and Iraq. Neurosciences 2008;13(3):276-282.

17.Daif AK, Al-Rajeh S, Awada A, Al Bunyan M, Ogunniyi A, AbdulJabar M, Al Tahan AR.Pattern of presentation of multiple sclerosis in Saudi Arabia: analysis based on clinical and paraclinical features. Eur Neurol 1998; 39(3):182-186. 